Article

\title{
'From Your Ever Anxious and Loving Father': Faith, Fatherhood, and Masculinity in One Man's Letters to His Son during the First World War
}

\author{
Martin Robb \\ Faculty of Wellbeing, Education and Language Studies, The Open University, Milton Keynes MK7 6AA, UK; \\ martin.robb@open.ac.uk
}

Received: 27 January 2020; Accepted: 20 March 2020; Published: 24 March 2020

\begin{abstract}
In the early months of 1916, Charles Robb a retired shipping clerk in the East End of London, England, wrote a series of letters to his 19-year-old son Arthur, an army private awaiting embarkation to the Western Front. Charles Robb was my great grandfather and Arthur Robb was my grandfather. The letters offer an intriguing glimpse of one man 'doing' fatherhood under conditions of traumatic separation and extreme anxiety. This paper presents an analysis of the letters from a psychosocial perspective, exploring the ways in which the writer exhorts his son to live up to the ideals of Christian manhood, while managing the anxiety of separation by presenting a reconstruction in language of the familiar world of home and church.
\end{abstract}

Keywords: fatherhood; war; masculinity; family history; religion

\section{Introduction}

On a Sunday evening in February 1916, a 65-year-old shipping office clerk from East Ham, a suburb on the eastern outskirts of London, England, sat down to write a letter to his 19-year-old son, a private in the Royal Fusiliers, who was stationed at Aldershot, Hampshire, awaiting transfer to the Western Front in France. The writer of the letter was my great grandfather, Charles Edward Robb, and the person he was writing to was my grandfather, Arthur Ernest Robb. The letter is one of a series of eight written by Charles Robb to his son on a more or less weekly basis between 6 January and 24 February 1916, which came into my possession after my grandfather's death. They had been preserved for half a century in my grandfather's wallet, which is a sure sign of their emotional importance for him. Sadly, only one side of the correspondence survives, as any letters that my grandfather may have written home have been lost.

Initially, my interest in the letters was purely personal, and I regarded them simply as useful background to my family history research. However, the more I read them, the more I came to see their potential as a resource for my academic research on fatherhood. When I looked more closely at these letters, it occurred to me that what they showed was a man actually 'doing' fathering. Most interactions between fathers, and indeed mothers, and their children are fleeting, evanescent, and difficult for researchers to observe or capture. Recent years have seen the field of fatherhood research growing exponentially, with ground-breaking studies of fathers' experience (for example: Doucet 2006; Dermott 2008; Miller 2010; Ranson 2015). However, despite the valuable insights that it offers, most research on fatherhood (including my own) is forced to focus on analysing fathers' reflexive constructions of their fathering practice, which is inevitably slightly removed from that actual practice (Robb 2004a, 2004b, 2020). However, letters between parents and their children provide a rare opportunity to see fathering, and indeed mothering, in action. In the case of my great grandfather's letters, written just over 100 years ago, there is also the opportunity to observe an example of fathering 
practice at a particular historical juncture, in a specific social context, and to assess it against rhetorical claims about fathering in the past. A further cause for interest in these letters is that they present an example of a man 'doing' fathering in the unusual conditions of separation and anxiety created by war and the very real threat of personal loss.

Moreover, the value of letters such as these is that they represent a kind of text that is increasingly rare. Before the age of the telephone, not to mention the smart phone and the internet, letters were the usual way in which family members separated by distance, or by extended periods of absence, communicated with each other, thus providing us with the kind of record that is rarely available in an age of texts and emails. What is more, an extraordinary event such as a war, with its experience of lengthy separation between family members and friends, has the side effect of producing extended series of correspondence.

However, it could be argued that these letters are also unusual, even in the context of First World War letter-writing, in that they are from a father to a son. Michael Roper, in his ground-breaking study of 'the battle for emotional survival of young British civilian soldiers on the Western Front in the First World War, and the part played by their families in that battle', writes that 'relationships with loved ones at home ... played a crucial role in sustaining the morale of this largely young, amateur army' (Roper 2010). Inevitably, these relationships had to be conducted remotely, 'through letters, parcels and other long-distance means'. However, Roper suggests that it was mothers, and not fathers, who were the principal correspondents with their soldier sons: 'Among the Imperial War Museum's collections of sons' correspondence from the Western Front there are almost six times as many letters to mothers as to fathers' (Roper 2010). Elsewhere, Roper concludes that 'the figure who appears least often in family correspondence is the father ... The letter was a feminine form, and because of its potential introspection and emotionality, for many mothers it felt a natural means of staying in touch' (Roper 2010). Nevertheless, Roper contends that 'examples of mothers' letters are hard to come by' (Roper 2010), which presumably means that examples of fathers' letters, such as those written by my great grandfather, are even rarer. More broadly, there has been a lack of academic attention paid to the study of fatherhood in the First World War by comparison with the impact of the Second World War on fathering practices (see for example, LaRossa 2011).

Besides his gender, there were other reasons why my great grandfather's letters caught my interest as a researcher on fatherhood and masculinities. One is that they seemed to demonstrate an emotionally expressive form of fathering that contradicted many of the stereotypes about Victorian and Edwardian masculinities. At the same time, these letters were shot through with my great grandfather's deep Methodist Christian faith: indeed, it seemed difficult to separate or disentangle his faith from his fathering. So, these letters offered a case study of a man 'doing' both fatherhood and religious faith, while these two aspects of his identity appeared interwoven in intriguing ways.

With these issues in mind, I set out to analyse the letters, looking for answers to four key questions:

- How does the writer 'do' fatherhood at a distance?

- How does he manage the anxiety of separation and the threat of loss?

- What is the relationship in these letters between fatherhood, masculinity, and religious faith?

- What light can the letters throw on our understanding of fatherhood in their specific historical context?

In what follows, I present my findings based on a close analysis of the letters. In addition, this article will also reflect on the more general questions raised by these letters and the experience of analysing them. These include questions about the validity or legitimacy of using material from one's personal family history as the material or basis for academic research. What kinds of methodological questions does this bring to the surface, and how should the researcher approach the use of 'found' material of this nature? 


\section{Background and Context}

Before presenting a detailed analysis of the letters, it will be useful to place them in their familial, social, and historical contexts. Born in Soho, London in 1851, the son of a law stationer's clerk and a mother who would die within weeks of his birth, my great grandfather Charles Edward Robb spent most of his childhood in Stepney in the East of London. His family were Methodists, and Charles' own series of lowly clerical jobs would include employment as housekeeper at the Wesleyan Mission in Whitechapel. Married at the age of 26 to the daughter of an umbrella maker, Charles was the father of eight children who survived beyond infancy, of whom my grandfather, Arthur, born in 1897, was the youngest. By the time of the 1901 census, the family had moved out from Whitechapel to the expanding working-class and lower-middle-class suburb of East Ham, on the Essex border. In 1902, Charles suffered the first of three serious bereavements, when his eldest son, also named Charles, a Royal Marine, died on active service in Aden at the age of 23. Three years later, Charles experienced two more losses within months of each other. In April 1905, his 16-year-old daughter Marion died from heart failure, and a few months later, his wife Louisa died from typhoid fever at the age of 48, leaving Charles to raise his surviving children alone. By the time of the 1911 census, he was living with his married daughter Louisa and her family; also with them were another daughter, Caroline (the 'Carrie' mentioned in the letters) and my grandfather Arthur. Before the outbreak of war, Arthur had worked as a brass finisher's apprentice. We know from other wartime letters that he was already 'courting' Polly Webb, the daughter of a Stepney bootmaker, whom he would eventually marry. Family legend would have it that when war broke out, my grandfather joined up as soon as he was able, perhaps even falsifying his age to ensure that he was eligible for active service in the Labour Corps of the Royal Fusiliers.

As already mentioned, the Robb family were Methodists. Founded by John Wesley in the $18^{\text {th }}$ century as a revivalist sect that eventually broke away from the Church of England, $19^{\text {th }}$ and early-20 $0^{\text {th }}$-century Methodism was distinguished by its overt emotionalism, an emphasis on a personal relationship with a loving Jesus, and by the involvement of lay people both in preaching and in self-government through the local 'class' system. The socialist historian E.P. Thompson (Thompson 2013) was famously disdainful of Methodism's emotionalism and could only see its influence on the emerging working class in negative terms, despite the fact that he himself came from a Methodist background. The historian of masculinity John Tosh takes an altogether more positive view of the Nonconformist movement's impact, particularly on gender relations. In his book on $19^{\text {th }}$-century masculinities and domesticity, Tosh discusses three case studies of Victorian couples who were committed to 'the Methodist way of life-the class, the chapel, the preaching, the hymn-singing' (Tosh 2007) and claims that 'Methodism furnished the materials for a feminine, as well as a masculine view of the world, and even for a measure of challenge to patriarchal authority' (Tosh 2007). The relationship between Methodism, masculinity, and fatherhood, in the context of my great grandfather's letters, will be discussed later in this article. Charles Robb's family background, his employment history, which included jobs as an office messenger and shipping clerk, and his Nonconformist affiliation meant that he and his family hovered on the borders between the 'respectable' working class and the lower middle class. Nothing is known for certain about Charles' political affiliations, but his letters show evidence of a robust patriotism alongside the all-important influence of his devout Methodism.

Charles Robb's letters to his son Arthur were written in 1916 at the height of the First World War (Fussell 1975). The second Battle of Ypres had been fought in the previous year, with the loss of about 60,000 British lives. The Battle of the Somme would take place later in 1916, with the loss of more than 19,000 British lives on its first day and 500,000 by the end of fighting in November. This is the theatre of war towards which my grandfather was heading at the time that his father wrote these letters to them. However, all of the surviving letters were written before Arthur left England and were addressed to him at Corunna Barracks in Aldershot, which was the main training ground for British infantry and a gathering point before embarkation for France. 


\section{Content and Structure of the Letters}

What did my great grandfather write about in his letters to his son, and how were the letters structured? In what follows, I will take as an example the letter that Charles wrote on Sunday 1916, one that is fairly typical of the series as a whole, and provide an overview of its content and structure. The letter is, similar to most family letters, something of a mixed bag, combining the serious with the trivial, the meaningful with the mundane. It begins with a reference to Arthur's previous letter and some continuing business about an undershirt that Charles had sent him, while later on, there is some other fairly trivial transaction6 Februaryal business: an address for a sister, a response to a request for a photograph.

However, the letter moves very quickly from these everyday concerns to expressing an intense anxiety about Arthur's current situation, which is framed initially as the writer's surprise that his son is not planning to come home on weekend leave:

\section{My Dear Arthur}

I received your letter yesterday acknowledging the Undershirt but was rather surprised to hear that you were not coming for the weekend. I do not know under what rule or regulation the passes are given in your section but I do hear that in most sections they are allowed by the Officer in Charge to a certain number of the best behaved and most attentive to duty during the week.

If this is the case in your section it does not appear to be altogether as it should be with you otherwise I am sure that you would have been able to obtain leave by this time.

I have been making enquiries from two or three who are able to inform me about the Fusiliers and they have made me almost to wish that you had not joined in that Reg[imen]t.

Then, there follows a long paragraph in which Charles exhorts his son, in explicitly religious language, to mind his moral behaviour:

Dear Arthur do take some advice from me, before you left home I begged of you not to associate yourself with bad companions. Remember you are an abstainer from all alcoholic drinks. Stick to the Temperance whatever it may cost you, likewise avoid in every way card playing or gambling betting and every means of dishonesty. I have not the least doubt that you will often find it rather difficult to avoid some or all of these Temptations. If the comrades with whom you are placed are mostly used to these things then not only for your sake but for my sake and all your Brothers and Sisters. There is still a Higher Sake for you to consider. Do try and Remember that you have always been taught the Supreme Great Truth that Christ Jesus came into the world to save sinners and that all through Him might be saved. Again I beg of you Arthur do not be led into following these awful Soul destroying habits. I am very much afraid that you have not at all times enough courage to say No when you are surrounded by Temptation You must Pray and Pray sincerely and earnestly and keep a Watchful eye wide open so that you can clearly see there is Temptation and do not be in the least afraid to meet it and Resist. Not alone in your own strength but keep your memory clear that God is Omnipresent always near you, always ready to hear your Prayer, always willing and anxious to Help you to persist. So I beg of you Arthur not to be negligent with Prayerfulness and Watchfulness. You are not praying alone. I have promised that I will always Pray for you, that promise is to me a Solemn Vow to God so when you find you feel weak Let God know all about it and remember that I too am praying for you.

This is followed by a short paragraph in which Charles advises his son to recall the words of a favourite hymn as a way of overcoming temptation:

If you cannot think of words at the moment that you feel depressed try and call to mind some Hymn verse that you know like this Shun evil companions. Bad-Language Disdain-God's Name hold in Reverence. Nor take it in Vain. Be thoughtful and earnest. Kind hearted and true

Look ever to Jesus. He will carry you through. 
The lines quoted in the letter are from Yield Not To Temptation, a popular Victorian hymn written by Horatio R. Palmer in 1868 . Then, there is a concluding paragraph in which the writer shifts the focus to himself and his own health and well-being:

In conclusion I must tell you this is Sunday evening and I have not been able to attend the Hall or any of the meetings as I am not at all well and am resting all day. It is very quiet and lonesome by myself but I must stand it till about the 26th when I expect that Carrie will be home again.

After this comes a final exhortation that returns to the main theme:

Now Arthur I beg you to read this letter and give it all the consideration you can and Do your very best to make a True Soldier not only for your King and Country but try and enrich your Loyalty by Faithfulness and whole Heartedness in your Service to God and His Son Jesus Christ who Loves you

The writer signs off:

From your ever anxious

And Loving Father

Charles Edward xx

\section{Methods of Analysis}

In setting out to analyse this and the other letters in the series, I used a methodological approach that drew on both the tools of discursive psychology and the insights of psychosocial research. Potter and Wetherell, in their classic text on discursive psychology, argue for paying attention to the function or purpose of a text, suggesting that 'people use their language to do things: to order and request, persuade and accuse' but that this should not be understood in a mechanical way: when people are persuading, accusing, requesting, etc., they do not always do so explicitly' (Potter and Wetherell 1987). Writing about the ways in which masculinities are constructed within discourse, Nigel Edley makes the claim that 'when people talk, they do so using a lexicon or repertoire of terms which has been provided for them by history' (Edley 2001). As Wetherell and Potter explain, the term 'discourse' has been used in many different ways. Some use the term 'to cover all forms of spoken interaction, formal and informal', whereas the influential French theorist Michel Foucault used it to refer to 'broader, historically developing, linguistic practices' (Potter and Wetherell 1987). For Foucault, discourse is 'a conceptual terrain in which knowledge is formed and produced ... the effect of discursive practices is to make it virtually impossible to think outside them' (Hook 2001; Foucault 1981) Drawing on a Foucauldian understanding of discourse and subjectivity, Lupton and Barclay argue that discourses, 'as ways of framing, speaking about and giving meaning to phenomena, are the sites of struggle, open to challenge from other discourses' (Lupton and Barclay 1997).

A discourse-analytic approach sees identity as multi-layered, non-unitary, and as established and performed in language. While psychosocial researchers would largely agree with this, they are also concerned with what motivates speakers or writers to invest in specific discourses, or particular discursive or rhetorical strategies. At the same time, psychosocial analysis, while sharing discursive psychology's general sense of the social construction of identity, is also interested in how social factors interact with personal factors. Drawing on the principles of psychoanalysis but refracted through a social lens, psychosocial research studies the ways in which subjective experience is interwoven with social life, maintaining that subjective experiences 'cannot be abstracted from societal, cultural, and historical contexts, but nor can they be deterministically reduced to the social'. Instead, social and cultural worlds are 'shaped by psychological process and intersubjective relations' (Association for Psychosocial Studies n.d.). As Stephen Frosh has argued, a purely sociological approach to personal experience risks 'flattening' out emotional life and reducing it to the interplay of social forces (Frosh 2002).

In his study of First World War letters, Roper raises the question of how the insights of psychoanalysis can assist an understanding of the emotional lives of young men on the Western Front 
without being reductive or over-speculative. He suggests that while Freud's original psychoanalytic insights on love, hate, loss, and trauma might be useful, for this specific purpose, Melanie Klein's object relations theory offers a more productive resource (Roper 2010; Klein 1986). Clearly, in Roper's case, Klein's emphasis on the primacy of relationships between children and their mothers is determinative, but her broader understanding of emotions and relationships might also inform an understanding of my great grandfather's strategies in his letters to his son. Roper writes that 'emotions for the Kleinian are not perceived as self-contained and individual, but as generated in human conduct and through communication - conscious and unconscious-with others' (Roper 2010, p. 24). In particular, a Kleinian-informed psychoanalytic approach can help to understand strategies for dealing with anxiety, Roper argues, and in particular for understanding omissions and evasions in the letters he analyses (Roper 2010). According to Hollway and Jefferson, common to all psychoanalytic schools is 'the idea of a dynamic unconscious which defends against anxiety and significantly influences people's actions, lives and relations' (Hollway and Jefferson 2000). This is clearly relevant to the present case study, which focuses on one man's rhetorical strategies for dealing with his own anxieties resulting from separation and the fear of loss. On the other hand, Roper echoes the 'common criticism of the use of psychoanalysis in history that we cannot put the dead "on the couch" ... and we cannot test our interpretations on our subjects as a psychoanalyst would' (Roper 2010, p. 25). The same applies to any psychoanalytically informed analysis or interpretation of textual material, which means that conclusions must inevitably remain speculative and open to contestation and revision.

In addition, a psychosocial approach to gender shares, with writers from a sociological perspective such as (Connell 1995), the notion that masculinities and femininities are plural, socially situated, and constantly formed and reformed in social interactions, rather than being static or biologically predetermined. However, a psychosocial perspective also includes a keen awareness that, to quote Peter Redman (Redman 2005), writing about research with boys, 'the various practices through which boys and young men [and one might add, all men] "do" masculinity are saturated with unconscious fantasy, intersubjective communication, and inextricably blurred boundaries between self and other.' Elsewhere, Redman and colleagues argue that 'psychoanalytic arguments can help us get to grips with the emotional labour involved in [everyday] activities, since they necessarily focus on the endless business by which unconscious anxieties and desires enter into and inflect our experience of the social world' (Redman et al. 2002).

A psychosocial approach, drawing at the same time on the tools of discourse analysis, can help us to see that Charles Robb's letters to his son are shot through with a deep sense of anxiety, and at the same time to identify the ways in which he uses language to deal with that anxiety.

\section{Conflict and Resolution}

If one were subjecting these letters to a rigorous discourse analysis, the first question one would ask of the texts would be: What are they trying to accomplish? What is it that motivates these texts, and what purpose or purposes are they setting out to fulfil? My analysis of my great grandfather's letters leads me to conclude that they are, first and foremost, struggling towards the resolution of a central underlying conflict between the writer's religious identity and beliefs on the one hand, and his son's current situation as a soldier in the British army about to go off to war on the other. I want to suggest that this tension is at the heart of, and is the driving emotional force behind Charles Robb's letters to his son, and it is one that the letters return to and worry away at repeatedly and in different ways.

Another way of expressing this is to suggest that the principal opposition in the letters is between two worlds: on the one hand, the familiar world of home, at the heart of which is the religious faith that Charles holds dear and to which he hopes Arthur also ascribes, and what is perceived to be the alien world of the army and the war. More specifically, it could be argued that the conflict to be resolved in the letters is between Charles' perception of his son's spiritual vocation as a Christian and his secular calling to serve King and country, which is a calling that Charles rhetorically endorses, 
while at the same time articulating a distinct sense of unease about its consequences for Arthur's spiritual well-being.

The letters are constructed in such a way that they move, or attempt to move, towards a resolution of this conflict. A clear example of their attempts at resolution is provided by the way in which a number of letters end, with a ritual bringing together of the two callings, the spiritual and the secular. For example, the letter of February 1916 already cited ends as follows:

Do your very best to make a True Soldier not only for your King and Country but try and enrich your Loyalty by Faithfulness and whole Heartedness in your Service to God and His Son Jesus Christ who Loves you.

There are similar examples in other letters:

God Bless You and make you a good Soldier of Jesus Christ so that it may Blend with your life as a Soldier for your King and Country.

God Bless you and make you a Good and Steadfast Soldier not only for King and Country but for Jesus Christ who Loves you so much.

These ritual and formulaic conclusions, which are similar to the blessing at the end of a religious service, combine the two vocations by using the traditional image of the Christian as a soldier of Christ, which is an image that was especially popular in Victorian and Edwardian Protestantism, coinciding with the heyday both of the British empire and of Christian missionary activity, and of which the words of the popular 19th-century hymn Onward Christian Soldiers provide a striking example.

However, on the way to these brief moments of ritual resolution, the letters contain all kinds of fractures and failures to resolve the two opposing positions. How does the writer of these letters deal with these conflicts and attempt to resolve them?

\section{Displacing Anxiety}

As we saw from the letter of 6 February 1916 quoted earlier, the focus of my great grandfather's anxiety in these letters is very much on the moral threat posed to his son by life in the army: the temptation to drink, to gamble, and so on. Charles Robb's expressions of concern about these threats become more intense as the series of letters unfolds, and there is a palpable sense of the distance between himself and his son creating an increasing sense of loss of control over Arthur's behaviour.

What is striking, certainly to the modern reader of these letters, is the absence of any reference to the very real physical threat posed by the war in which Arthur will soon be involved. At the same time, it is important to see things from Charles' perspective. To him, as a faithful Christian believer, what may seem to us with historical insight to be venal or trivial matters, when compared to the danger of death or injury in battle, might have appeared serious threats to his son's spiritual well-being and indeed to the fate of his very soul. At the same time, perhaps direct reference to the threat posed by war would have been taboo not just for my great grandfather, but for any parent writing to a son about to face such dangers. Therefore, a certain amount of avoidance of the subject, even to the extent of devoting precious space in the letters to the discussion of missing items of clothing or overdue subscriptions, might be said to be understandable.

However, on another reading, Charles' apparent obsession with venal temptations and domestic trivia can be interpreted as a displacement of his anxiety about the physical dangers faced by his son going to war and the very real threat of losing him. Even if we allow for the stringent demands of my great grandfather's Methodist faith and his teetotalism, the sheer energy expended in these letters on warnings and scoldings about drinking and gambling seems to speak to a deep level of repressed fear about that which cannot be mentioned in writing. Thus, at least some of what comes across as fear of losing his son to the apparently immoral culture of the army can be taken as a displacement of fear of a loss a more serious and permanent nature. Would it be too speculative to view these unspoken and 
repressed fears as intensified by Charles' previous experiences of loss, particularly that of his other soldier son?

In addition to the displacement of anxiety on to the moral culture of the army and domestic trivia, there is a third kind of displacement that is evident in the letters, in the perhaps surprising focus on concerns about the letter writer's own health. To the modern reader, it seems odd to see a father whose son will shortly be facing the prospect of injury or death in battle, complaining about his own minor health problems, especially given the magnanimous Christian concern for his son shown elsewhere. The ostensible aim seems to be to evoke sympathy in his son, and perhaps a sense of guilt, primarily at not coming home for the weekend, but perhaps also at an unspoken level guilt for volunteering to join the army and leaving his father alone. So, perhaps there is a tension here, albeit at an unconscious level and confusingly articulated, between Charles' ostensible patriotism and suppressed feelings of betrayal and loss exemplified by his son's departure for war.

At the same time, I would argue that the letters' repeated focus on the mundane objects and activities of home can be seen as fulfilling a positive function in relation to the letters' aim of reconciling the familiar and sacred on the one hand with the alien and secular on the other.

\section{Reconciling Two Worlds}

A key way in which the letters seek to redeem the alien world of the army and the war is by creating a bridge between the homely, faith-filled world and the hostile world of the army by projecting an image of the former world into the latter in written form. Interestingly, there are parallels here with the rhetorical strategies adopted by the poet David Jones in his First World War epic In Parenthesis (Jones 1937; Jones 1959), which I have written about elsewhere (Robb 1989) and which adopts a similar process of making the strange familiar or redeeming the 'unhomely' world, in Jones' case of the Western Front, by connecting it with 'homely' parallels. It might be argued that this strategy, in Charles' case, is as much for the benefit of the writer as the recipient of the letters; it is a way of overcoming fatherly anxiety as much as comforting and reassuring his son.

One interesting way in which the letters do this, and once again there are intriguing parallels with the work of 'sacramental' poets such as David Jones, is by reproducing the actual language of the 'homely' world, and more specifically the language of the chapel and the Sunday school in the text of the letters, interweaving these quotations with his own words in a multi-layered way. As was noted in relation to the first letter quoted earlier, there are whole passages that do not simply quote from the Bible or from familiar hymns and choruses but rather almost recreate in a ritual way a Methodist service, as if the writer is actually breaking into song.

What this strategy accomplishes is in effect to transfer in a very tangible, sensuous, and emotive form a simulacrum of the 'home' world that embraces not only family and home, but also faith and the weekly world of the church and all it signifies into the unhomely world of the army. Charles' strategy provides a connection between the two worlds, but it also aims to redeem the alien secular world of the army and the war by imaginative association, to bring them back into connection with the familiar spiritual world of faith, family, and home.

Roper (2010) writes about the way in which parcels from home acted for soldiers on the Western Front as a tangible expression of maternal love as well as an embodied reminder or representation of home. He gives examples not just of food but of other tokens of home such as a mother sending her son swatches of their new kitchen wallpaper, which are tokens that acted in an almost sacramental way (in a way that David Jones would have recognised and endorsed) as physical representations of 'home'. As Roper comments:

'Some might interpret these offerings as signs of civilian incomprehension of life in the trenches, but this was the stuff of home itself, and it offered the most direct contact short of going on leave. Historians, transfixed as they are by the written word and the drama of the trenches, have sometimes overlooked the significance of these ordinary domestic objects—now vanished—as conveying maternal love' (Roper 2010). 
Charles' tangible but seemingly trivial representations of home in words can be seen as fulfilling a similar function to these parcels, in this case acting as tokens of paternal love. John Tosh argues that there was something particular about Victorian Methodism's emphasis on the home as a spiritual entity:

'In drawing religion into the home at the same time as work was being taken out of it, the Methodists greatly intensified the hold of domesticity over the middle class and produced much of its characteristic tone and atmosphere. Methodism, like other forms of Evangelicalism, had its own theological rationale for locating so much religious observance in the home. It was a "religion of the heart" which valued the spiritual feelings of the individual. The relative intimacy of the small domestic gathering made space for an atmosphere of spiritual fellowship, in which the soul was bared, guidance sought, and reproof administered. This new dispensation, it has often been pointed out, enhanced the status of women, since it implied a new spiritual dimension to their traditional role as guardians of the hearth. But there were vital implications for men as well. What bound men to the home, in the early Victorian period especially, was not just the popular ethic of companionate marriage, or the emotional and material needs of the breadwinner, but the conviction that home was the proper place to cultivate one's spiritual well-being. The godly household was a corner of heaven on earth' (Tosh 2007).

\section{Fathering and Faith}

Discussion of my great grandfather's rhetorical strategy of forging redemptive connections between familiar and unfamiliar worlds prompts the question: what is the relationship in these letters between fathering and faith? One way of answering this is to suggest that Charles Robb's Methodist Christian faith provides him with two distinctive registers for his performance or practice of fatherhood and by extension for his identity as a man.

One of these registers has already been seen on display in the extract from the first letter quoted earlier. It is a register of moral exhortation with an insistent emphasis on courage, effort, and action. There are similar examples in other letters in the series:

Try and do all and everything of your Best in all things and do not forget the best way to conquer difficulties that seem almost impossible and are likely to conquer you is to use your own energy, capability, goodwill and endeavour.

I hope that you are getting on well and endeavouring in every way to do your very best. You are now placed in a position that everything you are told to do must be done immediately without any excuse for not doing it so keep up your courage and at every difficulty that comes in the way keep smiling and at all risks persevere until you conquer it Be active Be prompt Be careful Be willing Be diligent and then you will get on.

Dear Arthur I trust and pray earnestly for you that you will not forget the teachings of the Sunday School and the Scouts to Trust in God at all times and remember God for Jesus Christ's sake. God loves you not for a day but eternally and in answer to your Prayer assist you to overcome all difficulties and Temptation Do not forget to Be constant in Prayer and Watchful against Temptation.

We can see here one side of Nonconformist spirituality: the Puritan emphasis on working out one's own salvation with fear and trembling, and on individual effort, courage, and persistence, which are familiar from Bunyan's Pilgrim's Progress and Max Weber's famous analysis of the Protestant work ethic (Weber 2013). The connection with conventional images of Victorian masculinity should be apparent (Mangan and Walvin 1987). This aspect of his religious identity is a resource for a particular kind of masculinity in Charles' letters, one that is active, self-reliant, defensive, bounded, and wary of threats from outside.

However, alongside this, it is evident from the letters that Methodism provides Charles with another quite different register for performing fatherhood. Tosh (2007) has written about the ways in which Methodism provided a language that enabled Victorian men to be emotionally expressive, with its emphasis on the unconditional love of God and an intimate personal relationship with a loving Jesus, which was imagined often in quite feminine terms. A hint of this is seen in the final 
quotation above, with its reminder of God's infinite love for Arthur. Charles signs off one letter as 'your anxious and Loving Father' and adds two kisses. Another letter ends with the words 'With prayer from your Loving Father Charles Edward' and 'Love and Kisses from all'. Other letters in the series end in a similar fashion, with references both to the divine love of Jesus Christ 'who loves you so much' (24 January), 'Jesus Christ who loves you' (6 February), and to paternal love 'With abundance of Love and kisses from your father' (10 February), 'With love and kisses from your loving Father' (18 February), and so on.

These examples provides something of a corrective to the conventional image of the ways in which a 65-year-old man, brought up in the Victorian era, might have written to his 19-year-old soldier son 100 years ago. It suggests that another kind of masculine identity was available to men of this era from particular Christian backgrounds besides the austere stereotype of the self-reliant Puritan. The Christian, and specifically Methodist, image of the loving fatherhood of God provides Charles with a model for his own fathering, and at the same time, the emotional spirituality of Methodism offers him a language in which to openly express his love for his son. Tosh writes about one of the men in his case studies, a Methodist farmer from Lincolnshire, that his 'fatherly involvement' was 'not what we might expect of a Victorian father, much less a devout Methodist' and that fatherhood was integral to this man's 'sense of his divinely ordered place in the world, and inseparable from his masculine self' (Tosh 2007).

One might be tempted to characterise one of Charles Robb's rhetorical registers as more masculine and the other as more feminine, if we take masculinity as being conventionally associated with effort and action and femininity with expressivity and care. However, this is to fall back on stereotypical assumptions of what 'typical' fathering or masculinity might have been when Charles Robb was writing. To see him as unusual is to fall into the trap of viewing 'past fatherhoods' as the opposite of early 21st-century notions of caring or 'hands-on' fatherhood. One might argue that the contemporary discourse of 'new' fatherhood almost needs this stereotypical image of fathering in the past against which to define itself, although research by Tosh and other historians of fatherhood has done much to problematise the received picture of fathers' lack of engagement in the care of their children in the past: see for example Julie-Marie Strange's work on Victorian and Edwardian working-class fatherhoods (Strange 2015), Laura King's overview of post-First World War fatherhood (King 2015) and Ralph LaRossa's work on fathering practices in the inter-war period (LaRossa 1997). Part of the problem has been the absence of first-hand evidence of different fathering practices in the past, an absence for which I hope this analysis of my great grandfather's letters, as well as pioneering research such as that conducted by Tosh and others, might begin to compensate.

\section{Family History and Fatherhood Research}

The analysis of my great grandfather's wartime letters in this article prompts certain questions about the methodological legitimacy of using 'found' family history material of this kind as the basis for academic research. One question that is raised by this approach is the degree to which one can claim that the accounts analysed are in any sense representative of the broader spectrum of experience, in this case of fathering practice, in the period being studied. However, the same question might be raised about any other example of so-called 'micro history', or indeed any research using a 'case study' approach (Ginzburg 1993). The claim is not that these localised case studies are necessarily 'typical', but rather that their analysis lends a depth and richness to understanding of a spectrum of experience that is not available when using a wider historical lens. The same might apply to the burgeoning field of autoethnography, in which researchers use the example of their own experience as data (for example, see (Strasser 2016).

However, there are additional issues raised when using material from personal family histories as the basis for academic research. For example, the researcher, as a family 'insider', may have access to external data that could colour his or her interpretation of the material. This might take the form of direct personal knowledge of the writer or speaker, or in the case of more distant relatives such 
as my great grandfather, access to family stories and anecdotes, as well as a general 'feel' for the family context not available to an 'outsider' researcher. Again, some of these problems and issues are familiar from other kinds of 'insider' research, such as participant observation in ethnography (Hammersley and Atkinson 2019).

These factors would certainly create complications if one were adopting a purely discourse-analytic methodology, in which case one would want to rigorously exclude any information from outside the text. Clearly, both as a family 'insider' and as a family history researcher who has researched my grandfather's and great grandfather's lives, this was not possible for me, as it might have been for an outsider researcher coming to these texts without that knowledge. However, a psychosocial approach, with its interest in the personal factors behind an individual's investment in particular discourses, might take a more permissive attitude to this extraneous knowledge. At the same time, one needs to bear in mind Roper's caveat, mentioned above, about the dangers of psychoanalysing the dead.

To what extent, then, might what we know of Charles Robb's life experience from external sources help us to understand the strategies he adopts in these letters and the way in which he practices fathering? I have already referred to the fact that his life had been marked by a number of losses, beginning with the death of a mother whom he never knew, and followed by the deaths of two children and of his wife. Added to the experience of the latter bereavement, and as a consequence of it, is the fact that, to be the best of our knowledge, Charles had to raise his younger children as a single father, although we cannot know the precise circumstances of this, or whether there were other female figures-older sisters, or aunts, for example — who acted as maternal substitutes after the death of his wife Louisa. It is tempting to speculate that Charles was forced to act as both 'father' and 'mother' to Arthur, at least, as the youngest child (who was only 8 years old when his mother died), and this might lead us to conclude that the particularly expressive nature of Charles' letters, rather than being typical of fathers from his religious background or his generation, have resulted from his unusual role, for the period, as a single father.

As a researcher analysing my great grandfather's letters, it would have been difficult if not impossible for me to exclude this kind of extraneous information from my interpretation of the letters. However, as with all academic research, surely the response is to remain reflexively aware of the dangers of over-interpretation, to avoid speculative conclusions based on limited evidence, and at the same time to consider alternative explanations, all of which I hope I have done in this analysis.

\section{Conclusions}

My great grandfather's wartime letters to his son provide a rich case study of one man 'doing' fathering under difficult conditions of distance and separation in a specific social and historical context. Analysing the letters has demonstrated some of the ways in which particular rhetorical and discursive strategies may be used to displace overwhelming anxiety and to resolve seemingly intractable personal conflicts. At the same time, this analysis has cast light on some of the ways in which religious belief and masculine identity can interact, and the ways in which a particular religious tradition-in this case, Methodist Christianity — was able to provide a resource for an affective and expressive masculinity and fathering identity. It is to be hoped that this kind of 'micro-history', accompanied by rigorous analysis, can make a significant contribution to the growing social history of fatherhood and to the re-evaluation of stereotypical assumptions about fatherhood in the past, as well as contemporary debates about fatherhood and masculinity.

Funding: This research received no external funding.

Acknowledgments: An earlier version of this paper was presented at the Centre for Citizenship, Identities and Governance Forum on 'Fathers and Fatherhood' at The Open University, UK, in June 2013, and at the Annual Conference of the American Men's Studies Association, Ann Arbor, Michigan, USA, in April 2016. The author is grateful for the comments received from participants at these events.

Conflicts of Interest: The author declares no conflict of interest. 


\section{References}

Association for Psychosocial Studies. n.d. (undated) 'What Is Psychosocial Studies?'. Available online: http: //www.psychosocial-studies-association.org/about/ (accessed on 23 March 2020).

Connell, Robert William. 1995. Masculinities. Cambridge: Polity.

Dermott, Esther. 2008. Intimate Fatherhood: A Sociological Analysis. London: Routledge.

Doucet, Andrea. 2006. Do Men Mother? Fatherhood, Care and Domestic Responsibility. Toronto: University of Toronto Press.

Edley, Nigel. 2001. Analysing masculinity: Interpretative repertoires, ideological dilemmas and subject positions. In Discourse as Data: A Guide for Analysis. Edited by Margaret Wetherell, Stephanie Taylor and Simeon J. Yates. London: Sage/The Open University.

Foucault, Michel. 1981. The order of discourse. In Untying the Text: A Post-Structural Anthology. Edited by Robert Young. Boston: Routledge \& Kegan Paul.

Frosh, Stephen. 2002. Enjoyment, bigotry, discourse and cognition. British Journal of Social Psychology 41: 189-93. [CrossRef] [PubMed]

Fussell, Paul. 1975. The Great War and Modern Memory. New York: Oxford University Press.

Ginzburg, Carlo. 1993. Microhistory: Two or Three Things That I Know about It. Critical Inquiry 20: 10-35. [CrossRef]

Hammersley, Martin, and Paul Atkinson. 2019. Ethnography: Principles in Practice. Abingdon and New York: Routledge.

Hollway, Wendy, and Tony Jefferson. 2000. Doing Qualitative Research Differently: Free Association, Narrative and the Interview Method. London: Sage.

Hook, Derek. 2001. Discourse, knowledge, materiality, history: Foucault and discourse analysis. Theory and Psychology 11: 521-47. [CrossRef]

Jones, David. 1937. In Parenthesis. London: Faber \& Faber.

Jones, David. 1959. Art and Sacrament. In Epoch and Artist. London: Faber \& Faber.

King, Laura. 2015. Family Men: Fatherhood and Masculinity in Britain, 1914-1960. Oxford: Oxford University Press. Klein, Melanie. 1986. The Selected Melanie Klein. Edited by Juliet Mitchell. Harmondsworth: Penguin.

LaRossa, Ralph. 1997. The Modernization of Fatherhood: A Social and Political History. Chicago: University of Chicago Press.

LaRossa, Ralph. 2011. Of War and Men: World War II in the Lives of Fathers and Their Families. Chicago: University of Chicago Press.

Lupton, Deborah, and Lesley Barclay. 1997. Constructing Fatherhood: Discourses and Experiences. London: Sage.

Mangan, James Anthony, and James Walvin. 1987. Manliness and Morality: Middle-Class Masculinity in Britain and America, 1800-1940. New York: St. Martin's Press.

Miller, Tina. 2010. Making Sense of Fatherhood: Gender, Caring and Work. Cambridge: Cambridge University Press.

Potter, Jonathan, and Margaret Wetherell. 1987. Discourse and Social Psychology: Beyond Attitudes and Behaviour. London: Sage.

Ranson, Gillian. 2015. Fathering, Masculinity and the Embodiment of Care. Basingstoke: Palgrave Macmillan.

Redman, Peter. 2005. 'Who cares about the psycho-social?: Masculinities, schooling and the unconscious'. Gender and Education 17: 531-38. [CrossRef]

Redman, Peter, Debbie Epstein, Mary Jane Kehily, and Mairtin Mac an Ghaill. 2002. Boys Bonding: Same-sex friendship, the unconscious and heterosexual masculinities. Discourse 23: 179-91.

Robb, Martin. 1989. The Sacramental Vision: Belief and Art in the Poetry of David Jones, W.H. Auden and Charles Williams. PhD. thesis, Unpublished. University of Manchester, Manchester, UK.

Robb, Martin. 2004a. Exploring fatherhood: Masculinity and intersubjectivity in the research process. Journal of Social Work Practice 18: 3. [CrossRef]

Robb, Martin. 2004b. Men talking about fatherhood: Discourse and identities. In Communication, Relationships and Care: A Reader. London: Routledge/The Open University.

Robb, Martin. 2020. Men, Masculinities and the Care of Children: Images, Ideas and Identities. London and New York: Routledge.

Roper, Michael. 2010. The Secret Battle: Emotional Survival in the Great War. Manchester: Manchester University Press. 
Strange, Julie-Marie. 2015. Fatherhood and the British Working-Class, 1865-1915. Cambridge: Cambridge University Press.

Strasser, Daniel S. 2016. 'You Might Want to Call Your Father': An Autoethnographic Account of Masculinity, Relationships, and My Father. Journal of Family Communication 16: 64-75. [CrossRef]

Thompson, Edward Palmer. 2013. The Making of the English Working-Class. London: Penguin Books.

Tosh, John. 2007. A Man's Place: Masculinity and the Middle-class Home in Victorian England. London: Yale University Press.

Weber, Max. 2013. The Protestant Ethic and the Spirit of Capitalism. New York: Oxford University Press.

(C) 2020 by the author. Licensee MDPI, Basel, Switzerland. This article is an open access article distributed under the terms and conditions of the Creative Commons Attribution (CC BY) license (http://creativecommons.org/licenses/by/4.0/). 